\title{
見通し外伝搬によるテレビ伝送特性
}

\author{
$\begin{array}{llll}\text { 電電公社電気通信研究所 } & \text { 奥 村 善 } \\ \text { 中 } & \text { 村 親 市 }\end{array}$
}

\begin{abstract}
近年, テレビの兒通し外遠距離伝送の要求がさかんになり，その研究も各方面で 奏施されてきているが，果してどの程度の可能性があり，特性上どんな問題がある かは市するく知られていない, 見通し处伝送の方法には, 大別して対流圈散乱波 と山岳回折波を用いる二つの伝搬様式がめるが，テレビ伝送の特性上異なる点が多 いそここで本文では，主として山岳回折伝搬によるテレビ伝送の問題に関して，ま ずその伝搬特性を概説し，遠距離山岳回折回線に沶いてテレビの伝送特性を測定し た結果と, その改善対策について述べて市る。
\end{abstract}

テレビ变たは多重電話信号を見通し外の遠距離領域に 伝送する方法には, 大別して対流圈散乱波と山岳回折波 を利用する二つの伝搬㥞式がある.このうち山岳回折波 を用いると, 対流圈散乱伝搬様式による場合に比べて, いわゆ「山岳回折利得」によって伝搬損失が軽減でき， かつ, フェージングも少なくて S/N 面では有利な場合 がある、しかし遠距離になると受信電波の変動要因が多 くなり，また山岳からの多重回折波によって，テレビな ぞの広帯域云送にはかなり制限をうけ, ぞの程度の信頼 度で情報伝送がなしらるかは, 重要な問題であり, しか も岕京り知られていない，対流圈散乱波によるテレビの 見通乙外遠距離伝送の特性は，すで飞河野1)によって述 ベられているので, ここでは山岳回折伝搬の場合に限定 して, まず山岳回折伝搬特性を概説し, 若干の実験結果 にもとづきテレビ伝送特性について述べる.

\section{山岳回折伝搬の概 要}

\section{1. 伝搬損失とフェージング}

山岳回折伝搬は, 送・受信点の中間にある障害物とし ての山岳稜線から回折してくる電波を利用ずるものであ るが, 最も普通の場合として,山岳が一つ(単一山岳回折) の場合の基本伝搬損失 $\left(L_{b d}\right)$ は, つぎの式で与えられる.

$$
L_{b d}=L_{b f} \cdot L_{s} \cdot L_{a}
$$

ここに, $L_{b f}$ は送・受信点間の自由空間基本伝搬損失 で周波数と距離の 2 乗で增大する．ＬＳは山岳稜線を無 限長の厚みのない刃型とした場合, すなわちナイフ・エ シジによる回折損失で, 近似的に次式で求められる.

\footnotetext{
"Characteristics of Television Transmission Over the
} Horizon" by Yoshihisa Okumura \& Shinichi Nakamura.

$22(150)$

$$
\begin{gathered}
L_{s}=2 \pi^{2} v_{0}^{2} \quad\left(v_{0}>3\right) \\
v_{0}=H\left\{\frac{2}{\lambda}\left(\frac{1}{d_{1}}+\frac{1}{d_{2}}\right)\right\}^{1 / 2}
\end{gathered}
$$

この式の $v_{0}$ は回折パラメータで， $d_{1}, d_{2}$ は送受信点 と山岳との距離, $H$ は回折ナイフ・エッジの実効高（第 1 図の付図参照)，入は波長である. $L_{a}$ は回折山岳がナ イフ・エッジでないため, すなわち山岳の厚さ, 丸み, 山岳棱線の不規則性などによるため, あるいは山岳両側 の大地反射波，多重回折波などによって生ずる付加損失 で离る。第 1 図 ${ }^{2)}$ は多くの実測值（期間分布の $50 \%$ 值） から (1) 式の $L_{a}=1$ とした回折損失 $\left(L_{s}\right)$ を回折パラ メータ $\left(v_{0}\right)$ に対して理論値と実測值を比較したもので, $v_{0}$ が大きくなるにしたがって実測值は理論值より大き くなる傾向にある: これは(1) 式の付加損失 $\left(L_{a}\right)$ が $v_{6}$ の增大とともに大きくなることを示すもので, 実際の基 本伝搬損失を求めるには，(1)式の $L_{a}$ 亿対して，第 1 図の直線 (理論值) と点線 (実測平均值) との差の值を

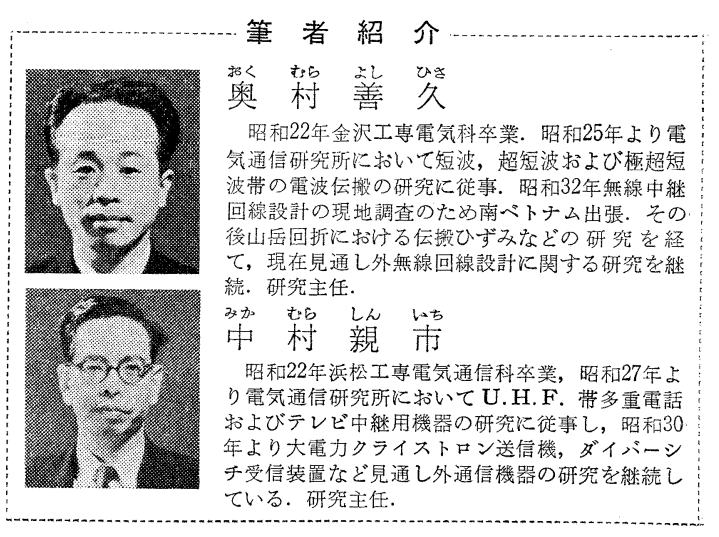


見远を㸚ばならない。

山岳回折伝搬炕新る フェージングは, 距離,

回折汕完の高さ, 周波数 に上って買なるが, 周波 数が高くなると回折山淩 線加らの多重波による電 界の干涉縞の移動が，フ ェージング発生の主な原 因となる。さら沉遠距離 の海上通路では海上ダク トなぞの影響がこれこ加 わる、第 2 図 $^{3)}$ は比較的

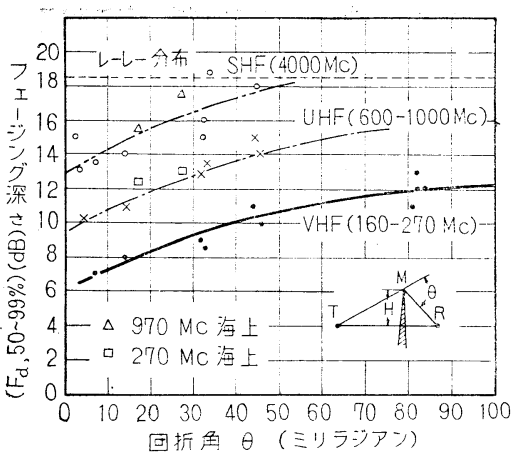

第2図山岳回折伝搬に括けるフェージング 深さ(艋50 400km の陸上単一回折通路最恶 月)

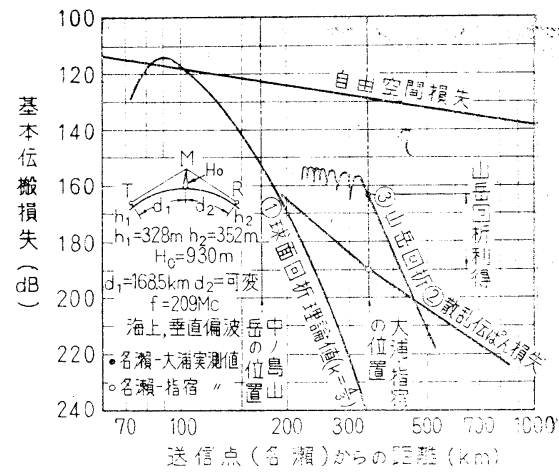

第3図付図の伝搬通路に和いて距離 を变光た場合の山岳国折利得の 計算例
多くの突験資料を，VHF，UHF 括上び SHF 营に分け，

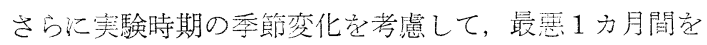
対象とし場合の分布に就る 50\%-99\%間の“フェー ジング深さ”を回折角 $(\theta)$ 亿対して示したもので，大雑 把和推定には十分突用しらる。海上通路で、VHF〜 UHF 帯汇詨して第 2 図の值のほぼ 1.4 倍 ( $\mathrm{dB}$ 值で) と みてよい、また VHF〜UHF 带では長期間のフェージ ング分布はほほぼ $\mathrm{dB}$ 正規分布とみなしてょい。

\section{2. 山岳回折利得}

山岳回折伝搬を対流圈散乱伝搬と比較するはに, 「山 岳回折利得」を一つの目安とすることができる。「山盘回 折利得! は, 伝搬路に回折山岳がない場合の基本伝搬損 失 $\left(L_{b s}\right)$ そ, 山岳が离る場合の基本伝搬損失 $\left(L_{b d}\right)$ の比 $\left(L_{b s} / L_{3 c} \equiv G_{M}\right)$ で定義され, 山岳がない場合の伝搬損失 として散乱伝搬損失を用いれば，この $G_{M}$ が 1 上り大 きいにど山岳回折回線が散乱回線に比べて有利で岕る.

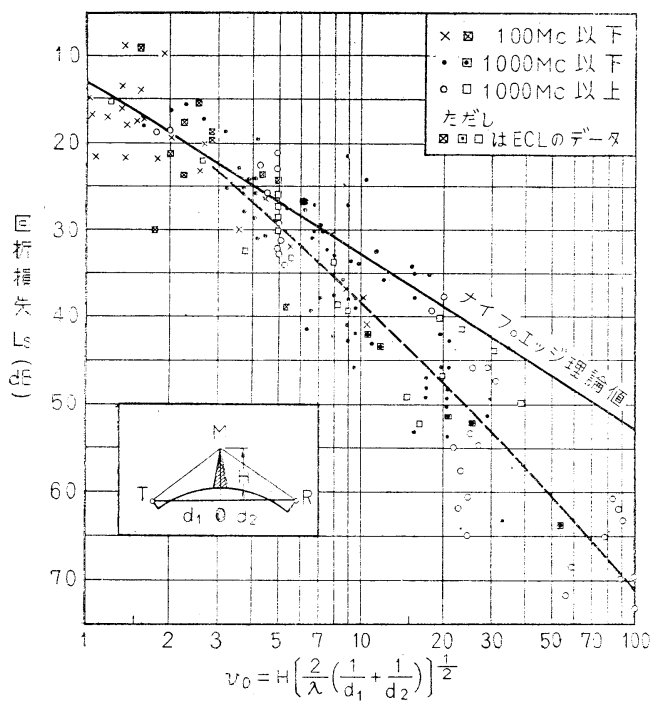

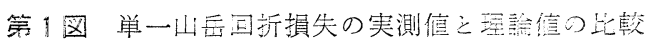

第 3 図 ${ }^{4)}$ ほこの関係を送信点 $(T)$ から $d_{1}=168.5 \mathrm{~km} の$ 位置に $930 \mathrm{~m}$ の山岳が女って, 受信点 $(\mathrm{R})$ の距離定变 えた場合を例にとって，209 Mc の電波に対する山岳回 折伝搬損失(曲線(3) 々散乱伝搬損失(曲線(2)) の計算曲線 を示したもので, 曲線(3)と(2)の差が山岳回折利得 $\left(G_{M}\right)$ となる。

図には電電公社の九州 (大浦)一奄美大島 (名瀬) 間の電 話, テレビ伝送のための山岳回折回線に扔いて名瀬送信 に対する大浦受信の実測值と，名瀬送信に対する散乱伝 搬路の受信点, 指宿 (鹿児島) (いずれも距離 $340 \mathrm{~km}$ ) に括ける実測值を比較してあるが， $G_{M}=27 \mathrm{~dB}$ 妾得て 特り，970 Mc では $G_{M}=24.5 \mathrm{~dB}$ を得ている。 この例 でみると距離 $200 \mathrm{~km} \sim 450 \mathrm{~km}$ では $G_{M}>1$ となり, 一般に送受信点から見通しとなる山岳が選べれば，山岳 回折が散乱伝搬に比べて, SN 比の面できわわて有利と なる。

\section{3. 山岳回折波における多重波}

山岳回折では回折体となる山岳稜線の不規則性交るい は山岳斜面から多重波が到来し, 受信電界はい方沙る地 域パターン（水平パターン）を生ずる。この多重波统， 散乱波に和㤝る多重波のようにわずかの通路差をむって ある領域で一様に広がっている場合と違って, 弧立した 成分波として観測される性質のものである。この多重回 折成分波の発生状況は，もっぱら回折山稜線の形状に依 存して和り, 回折山稜線が長くう㸚り続いている場合深 は, 回折成分波の数も多くなり, それらの通路差も大き くなって, 伝送带域幅淛限をうける。乙かし, 強い回 折成分波が発生するのは, 回折山棱の高さのほぼ 2 倍の 幅の領域 5 （主要回折領域之呼ぶ）で，普通の山岳では この山棱線領域から発生する回折成分波の数は, 周波数 によっても異なるが数波と考えてょい.

伝送帯域特性飞寄与寸る要素は，この回折成分波の振 幅比と通路差の大きさで，これを知るにはまず山稜線か 


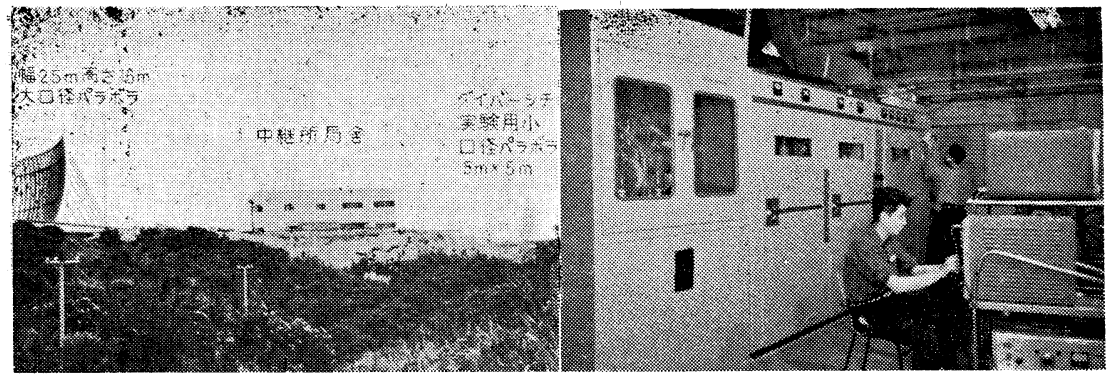

写真 1 受信アンテナ配置 (名瀬無線中継所)
写真 $2920 \mathrm{Mc}$ 実験用送信機 $(10 \mathrm{~kW})$ （大浦無線中継所内）
らの成分波の発生点を知らねばならない，回折山稯線が 単独山塊か単純な形状をしている場合には，山积線を梯 形あるいは部分的に直線に近似して最短通路の法則を用 いて求品られるが，一般的には「修正山稜線法」3) 6) 亿 よって求的らる。.この画き方は, 送受信点を結ぶ直線 と回折山无断面との交点をO（第 1 図の付図参照）と し，これ童原点として，第4図の $m_{1} m_{1}{ }^{\prime}$ 曲線のように 自然山稜線」を画く。つぎに，大円コースの通る自然 山碐線 $m_{1} m_{1}{ }^{\prime}$ 上の点 $\mathrm{M}$ と原点 $\mathrm{O}$ から水平距離 $x$ 飞対 乙て左右等間隔汇点をとり, $\overline{o a}=\overline{A a^{\prime}}, \overline{a b}=\bar{B} b^{\prime} \cdots \cdots$.... 上5再線 $m_{2} m_{2}{ }^{\prime}$ を画く。この $m_{2} m_{2}{ }^{\prime}$ 曲線が自然山 稜線 $m_{1} m_{1}{ }^{\prime}$ 汇対する「修正山稜線」で, この修正山稜 線汇抒いて轻平接線をるつ部分抒よび不運続点が回折成 分波の発生点となる. 特に水平接線をるつ部分飞強い成 分波が発生し，この水平部分のほぼ直線範团の長さと， $m_{2} m_{2}{ }^{\prime}$ 曲線の縱軸の大きさ $H(x)$ とがその成分波の強 度比汇関係寸る、第 4 図の例では, 強い成分波は矢印(1), (2), (3)の点に発生する.この回折成分波の通路差の最大 のるのが伝送帯域幅を決定することになるが，これは一 つの目安でめって, 実際にはすっと複雑で, 正確には統 計的表現によらねばならぬが，これは今後の問題であ る。な拨, 遠距離山岳回折では, 上述の回折成分波に通 路差が大きく振幅比の小さい散乱波成分が加わって, フ エージングの増大ととるに帯域幅の劣化が生ずる.これ らの対策としてては伝搬上からは, まずフェージングの深

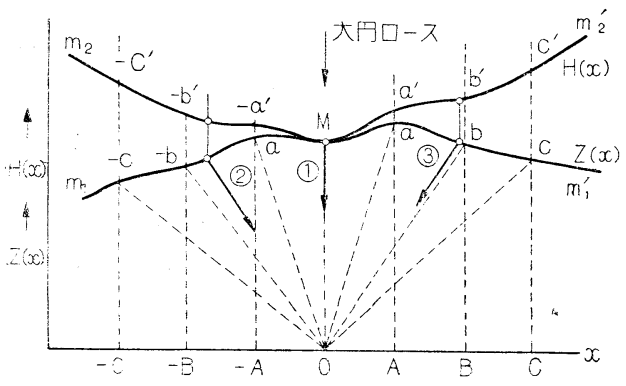

第4图回折成分波の発生点を求的修正山稜線法

$24(152)$
さを救済するとともに， アンテナビーム幅を狭く する必要がある.ぞの程 度のビーム幅にすればど の程度の帯域幅が得られ るかは, 山岳回折の場合 一般的に求めることは現 状では困難であるが，こ れはつぎに述べる実験結 果によってらかがうこと ができよう。

\section{山岳回折によるテレビ伝送特性}

\section{1. テレビ伝送試験の概要}

見通し外テレビ伝送に括ける特性は, 単に伝送可能带 域幅だけで評価してもあまり意味なく，これは一つの目 安にすぎないので，実際にはそれを俨価するに必要な各 種規格項目についての特性をみなけ机ばならない，ごの ため通研で法昭和 36 年 4 月〜 6 月に方たって，大浦（芘 児島）-名瀬（奄美大島）間 $340 \mathrm{~km}$ の海上山岳回折回線 に扮いて $920 \mathrm{Mc}$ の電波でテレビ伝送試験を実施した。

この通路のプロフィールは第 3 図の付図に示されてい るが，この試験では名瀬側が受信点となっている，写真 1 は受信側名瀬局の局舎, アンテナを示すもで, 写真 左側の大口径（高さ $16 \mathrm{~m} \times$ 幅 $25 \mathrm{~m}$ ) アンテナは実回線 用のものを容験飞共用したもので, 大溥送信もこれと同 形のものを用いた。 $920 \mathrm{Mc}$ に対する利得は $42 \mathrm{~dB} て ゙$, ビーム幅は水平 $\pm 0.45^{\circ}$, 垂直 $\pm 0.7^{\circ}$ である. 写真右 側の小口径 $(5 \mathrm{~m} \times 5 \mathrm{~m})$ アンテナはスベース・ダイバー シチの穾験用のもので, 利得は $32.5 \mathrm{~dB}$, ビーム幅は水 平 $\pm 1.5^{\circ}$, 垂直 $\pm 1.8^{\circ}$ である. 写真 2 は $920 \mathrm{Mc}$ の実 験用送信機で, 左からビーム電源部, 譇電源部, 制御部, 電力增幅部である. 電力增幅は Eimac 社の $4 \mathrm{~K} \mathrm{50,000}$ LQの 4 空洞クライストロンを使用して路り, 規格出力 $10 \mathrm{~kW}$ である。

\section{2. 伝送特性}

テレビ伝送の品質は，終局的には画質劣化の許容限界 から決めるべきであるが，これは物理的な要素の㴽が 心理的な要素も加わるので, きわめて複雑である。これ に対して波形伝送という点から，この画質との関係索文 るために, 主なものとして振幅一周波数特性, 位相一周波 数特性, 振幅変化-振幅特性 (微分利得), 位相-振幅特 性（微分位相）なぞの各特性汶対する規格が決められて いる.この伝送試験では，これら各特性に対する測定を 行なったが，ここでは主としてビデオ振幅特性，微分利 得特性尔々びテレビ画質について述べる。

テレビジョン 
（1） ビデオ振幅特性

この測定法は, 送信点大浦に特いてビデオ掃引発振器 を用い, 変調周波数 $0 \sim 6 \mathrm{Mc}$ の範囲に p-p $4 \mathrm{Mc}$ の周 波数偏移を与光, 周波数マーカを加えて送信し, 受信点 名瀬ではビデオ出力を検波器を通してシンクロスコープ に接続して, $8 \mathrm{~mm}$ カメラで撮像した. ビデオ振幅の変 化は，規格周波数 $0.8,3,4 \mathrm{Mc}$ 点の瞬時振幅を $0 \mathrm{Mc}$ 点の振幅々の偏差として求めた. ビデオ振幅は選択性フ ェージングによって時々刻々変化するが，この回線では フェージング姿態が種々な形を発生するので, フェージ ングのないときのビデオ振幅特性は, 送信特性とほとん ぞ変わりない，写真 3(a) はフェージングのない時間中 のビデオ振幅特性（1 秒間隔撮影）を示すものであるが, フェージングが発生すると写真 $3(\mathrm{~b})$ の上うに周波数の 中域で特性が割れたり, 高くなったり, あるいは高域が 低くなったりする変動が現われる。

さて，ビデオ振幅特性は信号波出力の基本波成分のひ ずみとして現われるもので, FM 伝送回路の振幅特性, 位相特性によって影響をうけ，一般に次式で表わされ $る^{7)}$.

$$
\begin{aligned}
A= & \frac{1}{2}\left[\left\{\frac{G\left(f_{0}+f_{m}\right)}{G\left(f_{0}\right)}\right\}^{2}+\left\{\frac{G\left(f_{0}-f_{m}\right)}{G\left(f_{0}\right)}\right\}^{2}\right. \\
& \left.+2 \frac{G\left(f_{0}+f_{m}\right) G\left(f_{0}-f_{m}\right)}{G\left(f_{0}\right)^{2}} \cos 2 \alpha\right]^{1 / 2} \\
\alpha & =\frac{1}{2}\left\{\varphi\left(f_{0}+f_{m}\right)+\varphi\left(f_{0}-f_{m}\right)-2 \varphi\left(f_{0}\right)\right\}
\end{aligned}
$$

ここに $G\left(f_{0}\right), \varphi\left(f_{0}\right)$ : 伝送回路の中心周波数での 振幅特性, 位相特性, $G\left(f_{0} \pm f_{m}, \varphi\left(f_{0} \pm f_{m}\right)\right.$ : 变調周 波数 $f_{m}$ の第 1 側波帯が 3 け振幅特性, 位相特性

また, 多重遅延波が存在する場合の伝送回路の振幅特 性を $G(\omega)$, 位相特性を $\varphi(\omega)$ とすれば

$$
\begin{aligned}
G(\omega)= & \left\{\left(\sum_{n=1}^{n} r_{n} \sin \omega \tau_{n}\right)^{2}+\left(1+\sum_{n=1}^{n} r_{n} \cos \omega \tau_{n}\right)^{2}\right\}^{1 / 2} \\
= & \left\{1+r_{1}{ }^{2}+r_{2}{ }^{2}+\cdots+r_{n}{ }^{2}+2 r_{1} r_{2} \cos \omega\left(\tau_{1}-\tau_{2}\right)\right. \\
& +2 r_{2} r_{3} \cos \omega\left(\tau_{2}-\tau_{3}\right)+\cdots \\
& +2 r_{n-1} r_{n} \cos \omega\left(\tau_{n-1}-\tau_{n}\right)+2 r_{1} \cos \omega \tau_{1} \\
& \left.+2 r_{2} \cos \omega \tau_{2}+\cdots+2 r_{n} \cos \omega \tau_{n}\right\}^{1 / 2} \\
& \varphi(\omega)=\tan ^{-1}-\frac{\sum_{n=1}^{n} r_{n} \sin \omega \tau_{n}}{1+\sum_{n=1}^{n} \cos \omega \tau_{n}}
\end{aligned}
$$

ここに， $\tau_{n}$ は遲延時間， $r_{n}$ は振幅比， $\omega$ は搬送角周 波数で女る.いま, これらの式を用いて，この大浦一名 瀬間山岳回折通路で存在する遅延波の性質を入れてビデ オ振幅特性を説明すると，つぎのようである．この通路 の回折山岳棱線 (中之島) は添湓富士山に似た形状をし て招り，頂上回折波を主波とすると，両側斜面からの回 折成分波の通路差は， $k$ (等価地球半径係数) 飞対して
第 5 図に示す值と なる、これらは短 い遅延波嘱する もので,このほか 飞散乱波成分尤 る遅延波の寄与が あり、これを等価 的にこの通路にお ける「主要散乱領 域」1)の上限から の遅延波と考光れ ば，その通路差は 約 $40 \sim 50 \mathrm{~m}$ とな り，その振幅比を 平均的江山舫回 折利得」の逆数と 考光れば, 約 0.05 となる、したがっ て, この通路では 前記の短い遅延波 とこの長い遅延波 によってビデオ特 性が招かされてい ると考觉ることが できる、短い遅延 波である回折成分 波の通路差は, 平 均的な $k=1.5$ で は $7 \mathrm{~m}$ そ $2.5 \mathrm{~m} て ゙$ あるが，いま簡単 のためこれを一波 に技きかえて通路 差をその差の 4.5 $\mathrm{m}$ のものとし, これと上記の長い 遅延波が加わ。 $\tau, \quad r_{1}=0.8, \quad \tau_{1}$ $=4.5 \mathrm{~m}, r_{2}=0.05$, $\tau_{2}=40 \mathrm{~m}$ の 3 波合 成に上る振幅特性 を，(6)式によっ て画くと第 6 図の ようになり，A点 を中心として效称 の形となる.この

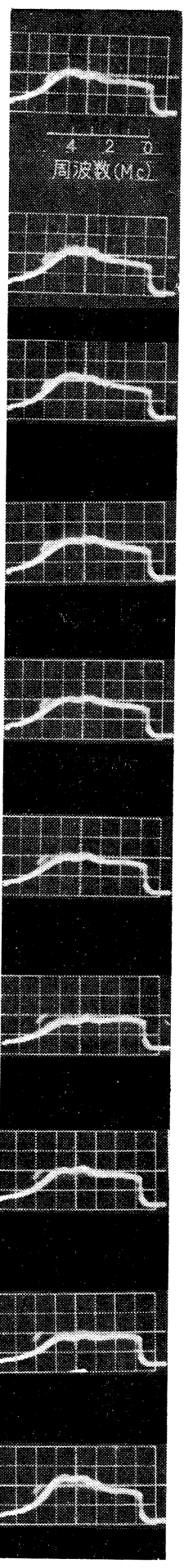

(a) 電界安定なとき

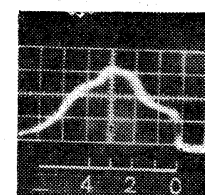

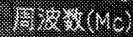
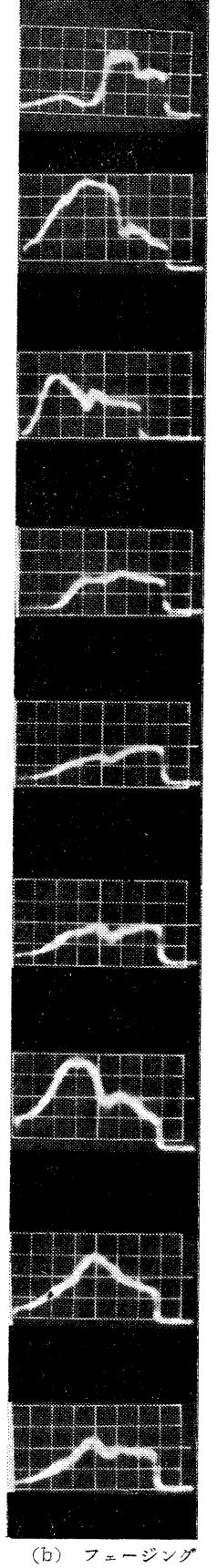

はダしいとき 
ような特性でビデオ振幅偏差を生ずるのは，大きい変曲 点 $A, B, C$ 点浬作点がある場合である.この 3 点汇着 目して(4)式から,フェージング深さ $F_{d}=20 \mathrm{~dB}, 15 \mathrm{~dB}$, $10 \mathrm{~dB}$ の場合, $f_{m}=4 \mathrm{Mc}$ 点のビデオ振幅偏差求的ると

(これらの点で法位相によって生ずる偏差は振幅特性に よるものに比べて圠較的小さい), 大体つぎの值となる.

$$
F_{d}=20 \mathrm{~dB} \quad 15 \mathrm{~dB} \quad 10 \mathrm{~dB}
$$

$$
\begin{array}{llll}
\mathrm{A} \text { 点 ビデオ编差 } & -13 \mathrm{~dB} & -9 \mathrm{~dB} & -5 \mathrm{~dB} \\
\mathrm{~B} \text { 点 } & +15 \mathrm{~dB} & +11 \mathrm{~dB} & +6 \mathrm{~dB} \\
\mathrm{C} \text { 点 } & -0.6 \mathrm{~dB} & \text {-左の值以下 }
\end{array}
$$

すなわら、フェージングによってA点に動作点すなお ち中心周波数が出るとき $4 \mathrm{Mc}$ 点のビデオ振幅は低くな

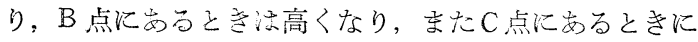
は㐫音り大きな变伦冲生じない，このような変化の様子 ほ写真 3 (b) に示す一連の特性に現われていることが 上くわかる。このように短い遅延波と長い荤延波が共存 する晅合には，䇺い湿延波の振幅比 $r_{1}$ の大きさが変化 する影響よりる，長い道延波の振幅比 $r_{2}\left(r_{2} \ll r_{1}\right)$ が变 化する方が，ビデオ振幅偏差が大きく現われる。

以上は遅延演の態が定常的状態嵓るときのビデオ 振幅偏差の様子芯説明したもので，その偏差の大きさは フェージングの大当さと関係をもつことが容易汇理解し

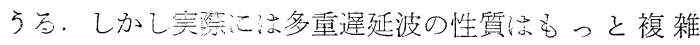
でたえず変化しているから，これを統計的な関係でみ れ心゙，第7医汇示す結果となる。この結果は，ビデオ振 幅特性を撮像している時間 (5分〜10分間) にわたって，
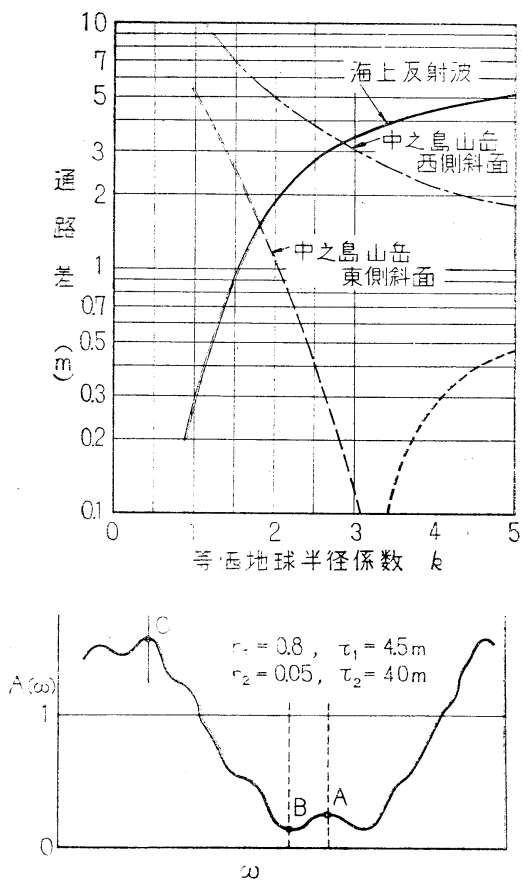

第 6 図

短い遅延波 と長い遈延波 ○3 波合成に よる多重路伝 般の脤幅特性 の計算例
$4 \mathrm{Mc}$ 点の振幅偏差が負となる（基点 $0 \mathrm{Mc}$ 点に対して低 〈なる） $1 \%$ 值と，その時間内のフェージング分布の 50 ; \% 99\%幅すなわちフェージング深さとの関係を示すも ので, 両者は活㯰線的関係で增大している。また大口 径アンテナ受信よりも, 小ロ径アンテナの方が, 同じフ ェージング深さに対して振幅偏差が大きく現われてお。 り，これは，アンテナ・ビーム幅が大きいと遠距離山岳 回折回線では散乱波成分の寄与が大きいことを示してい るとみてよいと考光られる. 第8 図は実験期間中毎日数 回ずつフェージングの各形態住して観測したビデオ振 幅特性の $0.8,3,4 \mathrm{Mc}$ 点の偏差の全期間飞わたる分布 の各\%値を示したもので, 受信アンテナの口径汇よる相 違を比較して女る.この結果から $4 \mathrm{Mc}$ 点の負偏差の 1 \%值は，大口径アンテナでは $7 \mathrm{~dB}$, 小口径アンテナでは $9 \mathrm{~dB}$ 程度で，振幅が低下する負偏差の周波数特性は各 \%值とも，ほぼ $A(f)=\exp \left(-\mu f^{\alpha}\right)(\mu, \alpha$ 定数, $\alpha=1.5 \sim 2)$ にしたがう傾向で変化しているょうで女 る. また上昇する正偏差の周波数特性は，ほぼ $A(f)=$

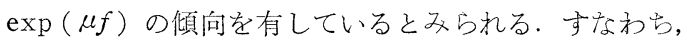
統計的にみると周数数が高いほど偏差は大きく, かつ負. 偏差の方が大きく現われる。この結果は, 見通し内テレ ビ中継回線に执ける規格（総合 $4 \mathrm{Mc}$ 点 $\pm 3.5 \mathrm{~dB}, 3 \mathrm{Mc}$ 点 $\pm 2 \mathrm{~dB}$ ) からみ机ば許容限界以上であるが, 対流圈散 乱回線に比べれば良好である。これらの特性の改善対策. は，伝搬上から久て水平面，垂直面ともビーム幅を狭く するほかに，スペース・ダイバーシチ方式の採用が考党 られる、しかし，ダイバーシチ受信に和ける広帯域特性 の改善効果は, きわめてむつかしい問題で, 合成方式も 直線合成（Linear adder）上りも2 乗比合成（Ratio Squarer) の方が望ましい，この実験で大口径と小口径. アンテナによる直線合成方式ダイバーシチ受信を行なっ た結果，第 8 図の特性よりは改善しているが，女まり顕 著ではなく, $4 \mathrm{Mc}$ 点負偏差の $1 \%$ 値は $-5.5 \mathrm{~dB}$ 程度で 岕った。

(2) 微分利得 (DG) 特性

この測定法は，送信側でリニヤリティ・チェッカによ り階段波形を $3.58 \mathrm{Mc}$ で変調し, 同期尖端から階段波 形尖端をで p-p $8 \mathrm{Mc}$ とし，3.58 Mc 正弦波の変調度を 10\%とし, 同期と階段波形の電圧比を $3 ： 1$ としたテス 卜信号を $12 \mathrm{~dB}$ エンフをマシスかけて送信し，受信側 ではこれを検波して $3.5 \mathrm{Mc}$ 成分の正弦波だけをとり出 してブラウン管の縦軸湤光, 横軸湶周波数を入れる と, AM 波形に似た図形が得られる。

これを $8 \mathrm{~mm}$ カメラで撮影して，その図形の最大振幅 $(M)$ と最小振幅 $(m)$ の差と最大振幅との比の百分率 $(M-m / M \times 100 \%)$ で整理した. このテスト信号では 


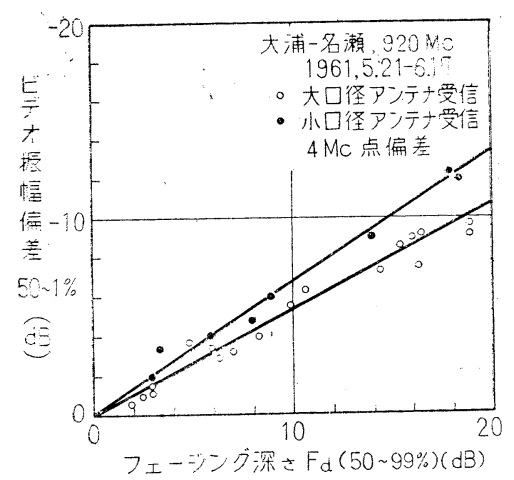

第7図フニージング深さと $4 \mathrm{Mc}$ 点 ビデ方标楅の負偏差との関倸
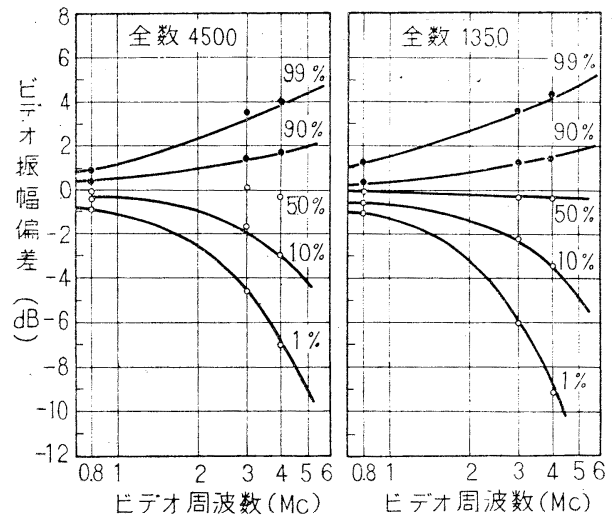

(a) 大口径アンテナ受信

(b) 小ロ径アンテナ受信

第 8 図ビデオ振幅偏差の全期間分布の各\%值 (大浦 - 名瀬)
信号の全範国の各部の直線性（微分俌）が走查されるこ とになり, 重墨された正弦波の振幅は各部の直線性の微 分逼に応じて変化するので, 受信波形によって非直線ひ ずみの大きさを㓤ることができる。これが伝送回路の微 分利得 $(D G)$ 乙い方れている. 写真 4 は $D G$ の観測例 で、フェージングのないときは振幅はまったく平坦であ るが, フェージングの発生によってこれも大きく変化す る。 $D G$ 任运系の振幅特性が大さく支配し，この場合 近优的に次式で空わされる8).

$$
D G=\frac{\frac{G\left(f+f_{m}\right)+G\left(f-f_{m}\right)}{2 G(f)}}{\frac{G\left(f_{0}+f_{m}\right)+G\left(f_{0}-f_{m}\right)}{2 G\left(f_{0}\right)}}-1
$$

上式に捼いて， $f_{m}$ は微分周波数(この場合 $3.58 \mathrm{Mc}$ ) で，分母の記号洫(4)式と同様で，分子の記号は $f_{0}$ が $f に$ にった場今と同様に考えればよく, $f$ は周波数偏 移に相当し，こD害験では p-p $8 \mathrm{Mc}$ に詨して $12 \mathrm{~dB}$ エ

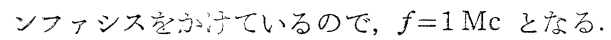

さて，この奉験伝搬路のように短い塀延波と長い遅延 法功共存する場合, 遅延波の要素を前項と同様としてフ エージング深さ $20 \mathrm{~dB}$ のと, 第 6 図のA, B 点に動作 点があると劣つ $D G$ を（8)式から求めると，A点では

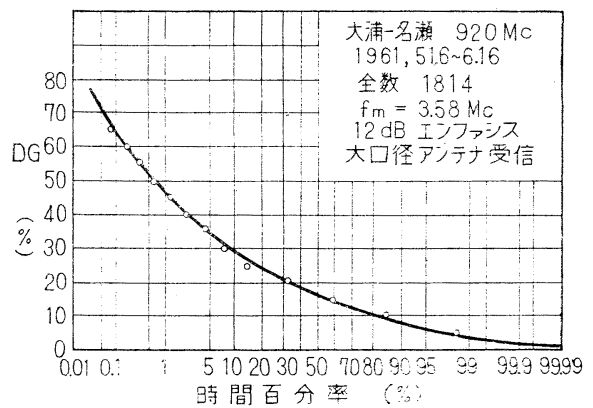

第 9 回 徽分利得 (DG) ○全期間分有
約63\%，B点では約70\%発生するこ とになる。しかし前にも述べたよう に実際には遅延波の性質柱たえず変

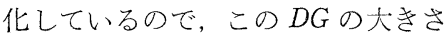
を統計的にみれば，第 9 図の分布と なる．白黒テレビでは重罩する高周 波正弦波の周波数 $f_{m}$ は $0.2 f_{c}=0.8$ $\mathrm{Mc}\left(f_{c}\right.$ は映像信号の最高周波数で 525 本方式では $4 \mathrm{Mc}$ ) とする規格 となって宗り， $f_{m}=0.8 \mathrm{Mc}$ の場合 の $D G$ は微分周波数の 2 乗比で变化 すると考光られるから，第 9 図の結 果から $1 \%$ 值は $2.3 \%$ と推測され る.この值は, CCIR の総合規格 20\%からみればそれ核ぞ惡い值で はない.この $D G$ は白黒テレビの 場合コントラス々を損ら度合を示す が，NTSC 方式カラーテレビの場 合 $3.58 \mathrm{Mc}$ の副搬送波の明度信号 に対する振幅比で色の飽和度を伝送 しているので，これは飽和度の忠実 度に対する尺度となり， $f_{m}=3.58$ $M c$ での $D G$ は第 9 図の分布となる ので，この回線は現状ではカラーテ レビ伝送には適さないようである (規格け総合で $10 \%$ 以内).

\section{（3）テレビの画質}

テレビ画質の試䥒には，TIE-4 型工業用テレビ装咀 (ITV) を用い て普通の絵またはテストパターンを 撮像し， p-p $8 \mathrm{Mc}$ の周波数偏移の 周波数变調で送信したものを, 受信

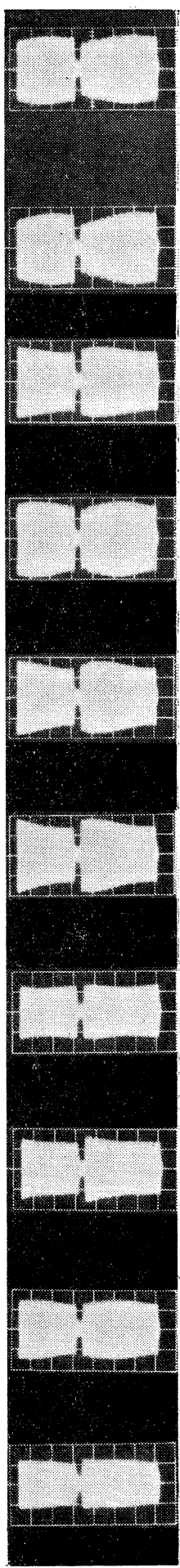

写真 4 DG(微分 利得) の観測例 $(12 \mathrm{~dB}$ ニンフ フシス)

(155) 27 


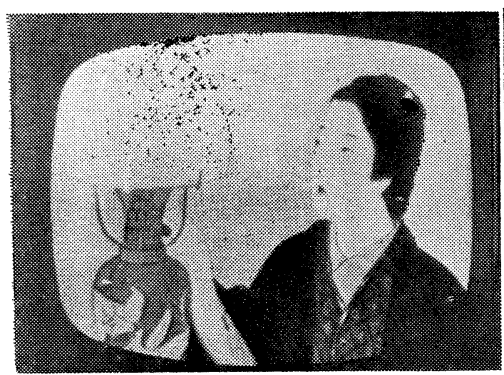

写真 5 受像例 (電界安定のとき)

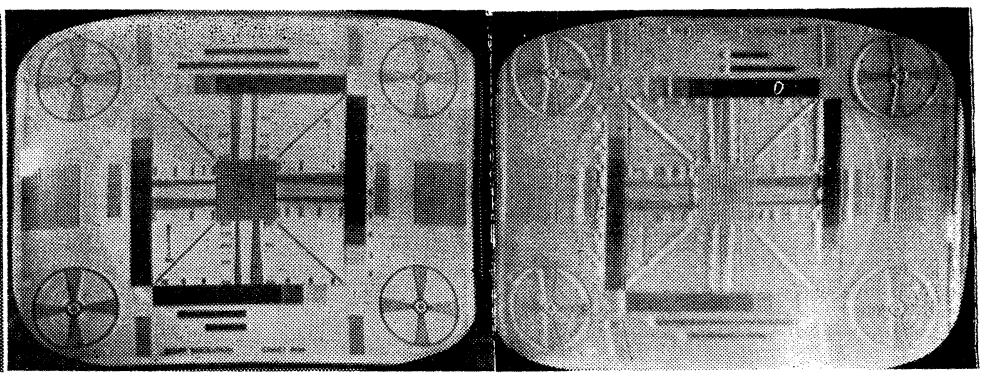

(a) 電界安定のとき (b) 深いフニージング発生時

の受像例
側では受信機のビデオ出力を監視用受像機（普通の17イ ンチ受像機）に接続して，16mm カメラで連続撮影した. この場合, ITV の水平解像力は 350 本, 垂直300本程度 で，監視用受像器はそれ以下であるので，画質はもとも と最良質ではなく，したがって画質の微細な変化の試験 には不向きであり，画質の大きな変化に着目した.この 回線では受信電界がきわめて安定な時間がかなり多いの で，この場合には受信画質も装置の性能の範囲できわめ て良質である.したがって，画質の大きな変化もこのと きの画質を基準として比較判定した，写真 5 和よび写真 6（a）は受信電界の安定なときの画質を示し，フェージ ングが発生すると, 画質劣化の主な現象として解像力の 劣化, コントラストの変化および白黒反転様の劣化を生 ずる.この後者の劣化で極端な場合は写真 $6(\mathrm{~b})$ に示す ような例で, 深いフェージングのとき発生している. 解 像力およびコントラストの少化は, 前述のビデオ振幅特 性および $D G$ 特性の変動結果からも相当生ずることがわ かり, 白黒反転様の劣化はもちろん前二者の程度のはげ しいものであるが，選択性フェージングによる振幅特性 の変動のほか，高い周波数成分の位相ひずみが大きな影 響を及ぼしているものと考兄られる．画質劣化を定量化 することはむりかしく残された問題であるが，その一つ の目安として，上記 3 種の画質劣化が生じたときの瞬時 フェージング深さを調べると，第10図に示す分布とな る.これは小ロ径アンテナ受信結果で, 画質劣化は, 瞬

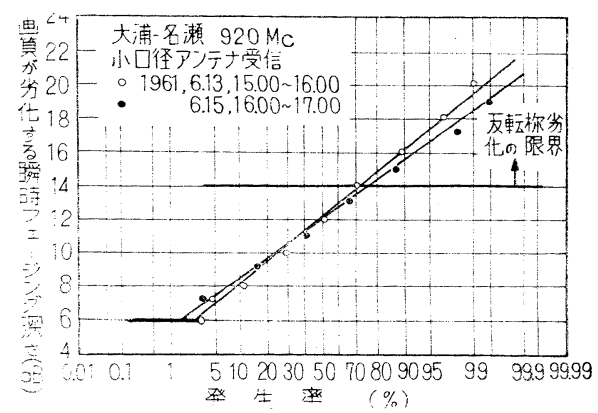

第 10 図画質劣化と瞬時フェージング深さとの関係
時フェージング深さが $6 \mathrm{~dB}$ ぐらいのときから発生し， $14 \mathrm{~dB}$ ぐらいから写真 6 (b) 飞示すよ5な白黑反転様の 劣化を生じている. 第10図の結果からは, やはり画質劣 化の程度はわからぬが，フェージング深さの小さいとき には劣化の程度も小さいとみるべきで, この関係は第 7 図の結果からも推測がつくと考学られる.

\section{むす び}

以上山岳回折伝搬特性と遠距離山岳回折回綄に括ける テレビ伝送特性の実験結果の概要を述べたが，山岳回折 回線ではSN 比を十分確保することは現状では容易であ るが，広带域伝送特性をきわめて良好に传特するには困 難な問題がある.しかし伝送特性は散乱回線に比べれば 良好であると考えられる。

テレビ画質の改善には, 尖鋭なビームのアンテナを用 い,かつダイバーシチ受信を採用することは有力な手段 であるが，ダイバーシチ方式で十分改善し5るとは限ら ないので，その合成方法の検討とさらに画覧劣化の発生 機構を解明して別な改善効策を講じてゆく必要がある.

これは今後に残された間題として重要である.

終りに，実験に指導と協力をいただいた深海前無線蒋 長, 土井無線課長補佐, 森永無線課長補任, 牧野無線方 式係長を始め実験を担当した通研無線課の同僚, ならび に九州通信局調查課, 福岡無線通信部の關倸諸氏に深く 謝意を表する。（昭和 36 年12月5日受付）

\section{[参考文 献]}

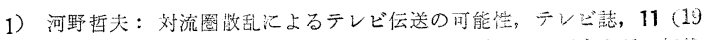

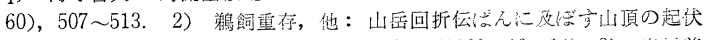

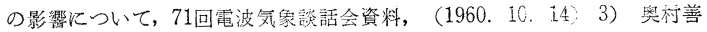

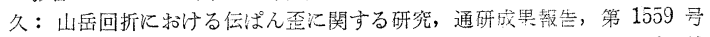

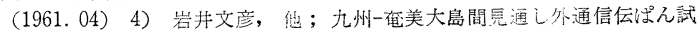
験, 通研赛報, 9 (1959) 1183 1213.5) 平井正一; 超䄈波山岳回析波 の多重路伝ぱん機構之回折損尖, 電波研季報, 4 No.16 (1958.07) 6) 奥村善久, 他：超短波の山岳回折汇㧠斿る伝ぱんひずみ, 信学誌 10 (19 61) $1354 \sim 1362.7$ ) 营原鼎近甍：FM 無線工学, 日刊工㗬新聞社, (19 59) 589 594. 8) 松本高士, 偈：FM 伝送系に利け石小さなエコーが

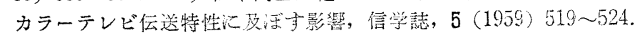

